Situs Jurnal : http://ejurnal.stiepancasetia.ac.id/index.php/jieb

Jilid 4 Nomor 3 November 2018

Hal $301-318$

\title{
ANALISIS KELAYAKAN USAHA PENGOLAHAN IKAN PADA INDUSTRI KECIL CASHEILA BANJARBARU
}

\section{Illya Yudha Maharani, Firda Nosita* dan Asruni}

Abstract: The purpose of this study is to determine the feasibility of developing casheila business from financial and non financial aspects as well as analyzing the company's sentiment towards changes in raw material and decline in production. The method used is Descriptive Qualitative and Quantitative, which is to assess the business of casheila industry to the feasibility of business in the future. Based on the results of research from the marketing, technical and technological aspects of casheila business is feasible to run, while from the aspect of management and human resources is quite simple, it is necessary to improve the managerial system for business continuity in the long term. The result of financial aspect analysis through assessment method is feasible to run based on the calculation of PP (Payback period), Capital is for 1 year and a month, shorter than maximum Payback period. NPV (Net Present Value) is in Positive Value of Rp 1,191,596,184. While the result of the calculation of PI (Profitability Index) is 4.96. This shows the comparison of project benefits far greater than the cost required. And the value of IRR (Internal Rate of Return) is $24.54 \%$ greater than the prevailing interest rate of $14.08 \%$. While the sensitivity analysis on the decrease of production of analytical results worth $44 \%$ and the increase in raw materials worth $43 \%$ experienced a significant change.

Keywords: business feasibility study, small industry, financial aspect, non-financial aspect

Abstrak: Tujuan Penelitian ini adalah untuk mengetahui kelayakan pengembangan usaha industri kecil casheila dari aspek finansial dan non finansial serta menganalisis sentivitas perusahaan terhadap perubahan kenaikan bahan baku dan penurunan produksi. Metode yang digunakan adalah Deskriptif kualitatif dan Kuantitatif, yaitu memberikan penilaian pada usaha industri casheila terhadap kelayakan usaha di masa yang akan datang. Berdasarkan hasil dari penelitian dari aspek pemasaran serta aspek teknis dan teknologi usaha industri casheila layak untuk dijalankan, sedangkan dari aspek manajemen dan sumber daya manusia masih terbilang sederhana, diperlukan peningkatan sistem manajerial untuk kelangsungan usaha dalam waktu panjang. Hasil analisis pada aspek finansial menunjukkan bahwa usaha cashiela layak untuk dijalankan. Berdasarkan hitungan PP (Payback periode), Periode Pengembalian Modal adalah selama 1 tahun 1 bulan. NPV (Net Present Value) bernilai Positif Sebesar Rp 1.191.596.184. Sedangkan hasil perhitungan Indeks Profitabilitas (PI/Profitability Index) yaitu 4,96, hal ini menunjukan perbandingan benefit proyek yang jauh lebih besar dari biaya yang dibutuhkan. dan nilai IRR (Internal Rate of Return) 24,54\% lebih besar dari nilai bunga yang berlaku yakni $14,08 \%$. Sedangkan dari analisis sensitivitas pada penurunan produksi hasil analisis senilai $44 \%$ dan pada kenaikan bahan baku senilai $44 \%$ mengalami perubahan yang signifikan.

Kata kunci : studi kelayakan bisnis, industri kecil, aspek finansial, aspek non finansial 


\section{Latar Belakang}

UMKM (Usaha Mikro Kecil Dan Menengah) merupakan salah satu penggerak perekonomian nasional yang terbukti tahan terhadap adanya krisis ekonomi. Hal ini dapat dipahami karena UMKM merupakan kegiatan ekonomi rakyat dengan skala kecil, dan bukan kegiatan ekonomi yang dikuasai beberapa orang. Beberapa keunggulan UMKM dibanding usaha berskala besar seperti dinyatakan Partomo dan Soejoedono (2004 : 45) adalah : (1) Inovasi dalam teknologi yang telah dengan mudah terjadi dalam pengembangan produk, (2) Kemampuan menciptakan kesempatan kerja, (3) Fleksibilitas dan kemampuan menyesuaikan diri terhadap kondisi pasar yang berubah dengan cepat dibanding dengan perusahaan skala besar yang pada umumnya birokratis, dan (4) Terdapat dinamisme manajerial dan peranan kewirausahaan. UMKM saat ini telah menjadi sumber kehidupan bagi sebagian besar rakyat Indonesia.

Dari sekian banyak UMKM di kota Banjarbaru, salah satu bidang usaha yang potensial adalah usaha makanan. Usaha makanan merupakan usaha yang potensial, salah satu alasannya karena kebiasaan masyarakat yang mulai berubah yang menginginkan makanan yang cepat saji dan praktis dari pada membuatnya sendiri. Peluang tersebut tidak disia-siakan oleh para pengusaha yang ada di Kota Banjarbaru. Pangan adalah kebutuhan pokok manusia hal itu menjadi dasar bagi para pelaku bisnis untuk membuka dan mengembangkan usaha di bidang makanan.

Pada sektor kelautan dan perikanan usaha pengolahan hasil perikanan pada umumnya masih didominasi oleh pengolahan ikan berskala usaha mikro, kecil dan menengah. Usaha pengolahan perikanan umumnya masih bersifat tradisional, cenderung dikelola oleh keluarga secara turun-temurun dengan kapasitas produksi yang terbatas dan kegiatan usaha bersifat rutinitas. Usaha pengolahan hasil perikanan berskala mikro dan kecil biasanya memiliki keterbatasan pada beberapa aspek, seperti permodalan, teknologi dan informasi, manajemen dan pemasaran, sehingga terkadang belum mampu bersaing dengan produk lainnya. Mereka juga dihadapkan pada kesulitan melakukan penguatan internal, seperti peningkatan produktivitas, riset pengembangan produk, pelatihan dan bimbingan SDM serta promosi usaha.

CASHEILA adalah salah satu usaha kecil menengah yang menggeluti usaha panganan di Kota Banjarbaru. Usaha ini belum lama berdiri sehingga masih membutuhkan banyak masukan. Dalam suatu usaha baik dalam skala kecil maupun besar sebaiknya memiliki studi kelayakan usaha. Studi kelayakan usaha diperlukan untuk melihat sebuah gambaran mengenai layak atau tidak layaknya suatu usaha yang akan dijalankan. Sebelumnya perusahaan ini belum melakukan analisis terhadap kelayakan usahanya, maka penelitian ini dilakukan, agar dapat menjadi masukan bagi perusahaan.

Untuk aspek manajemen masalah utama yang dihadapi adalah rendahnya kualitas SDM, kemudian untuk aspek legalitas menyangkut masalah kompleksnya mekanisme dan prosedur perizinan, untuk aspek permodalan menyangkut masalah terbatasnya akses terhadap perbankan karena ketatnya persyaratan Bank yang harus dipenuhi, sedangkan untuk aspek pemasaran dan produksi masalah utama yang dihadapi adalah terbatasnya akses informasi pasar, jaringan distribusi dan teknologi.

Pada dasarnya, keberadaan Casheila tidak lepas dari usaha pemiliknya untuk memenuhi kebutuhan ekonomi dan meningkatkan taraf hidup. Ada banyak faktor yang menentukan kesuksesan suatu usaha diantaranya peluang pasar, kondisi persaingan, tren bisnis, dan lainlain. Oleh karena itu, secara teori tidak cukup hanya mengandalkan insting dalam mengambil keputusan di dunia bisnis. Lebih dari itu, diperlukan suatu kalkulasi yang komprehensif baik secara kualitatif maupun kuantitatif dari segala aspek yang berkaitan dengan usaha yang akan di buat. Agar Casheila dapat bersaing dan memiliki prospek perkembangan yang bagus. Dalam menjalankan usaha diperlukan sebuah studi kelayakan apakah sebuah usaha layak 
dijalankan atau tidak layak dijalankan. Jika layak untuk dijalankan, landasan apa saja yang menjadikan layak dan juga jika tidak layak, faktor-faktor apa saja yang menyebabkan ketidaklayakan usaha tersebut. Studi kelayakan bisnis juga berguna untuk memperhitungkan kemungkinan apakah bisnis tersebut dapat bersaing dan bertahan diantara para kompetitornya sekaligus melihat kemungkinan pengembangan di masa depan dilihat dari berbagai aspek.

Berdasarkan wawancara yang peneliti lakukan dengan pemilik Pengolahan Ikan pada industri kecil cashela hingga saat ini industri ini belum dapat berkembang sesuai dengan apa yang diharapkan, padahal industri ini sangat menjanjikan. Hal itu dikarenakan kurang maksimalnya pemasaran dan kinerja industri ini. Pemasaran produk Cashela ini juga luas, karena pemasaranya langsung pada sentra oleh-oleh yang ada di kalimantan selatan dan penjualan online. Bisa dilihat pada tabel 1.1.

Bahan baku diperoleh dari beberapa pemasok tetap sehingga ketersediaannya terjamin. Bahan baku utama yang digunakan adalah ikan sepat dan ikan gabus. Permasalahan teknologi dan inovasi produk sangatlah penting bagi keberlangsungan suatu UMKM. Kemasan produk yang belum memenuhi standar di Indonesia dimana sifat produk dengan ketahanan yang pendek dengan kata lain produk-produk yang dihasilkan akan lebih mudah rusak.

Dalam upaya mencari solusi atas permasalahan yang dihadapi, yaitu meningkatkan kapasitas usaha berskala ekonomi dengan kelembagaan yang kuat serta dikelola secara profesional dengan akses dan penetrasi pasar yang kuat dan berdaya saing, serta mampu berproduksi lebih efisien dalam kawasan pengembangan, maka diperlukan penerapan konsep pengembangan industri pengolahan hasil perikanan. Akan tetapi dalam perkembangannya, fasilitas yang disediakan meliputi penyediaan sarana prasarana yang ada tidak berfungsi sesuai dengan harapan. Di samping itu konstruksi bangunan belum memenuhi standar karena dari segi sanitasi dan hygienitas kurang memenuhi syarat, sehingga berdampak pada kualitas dan mutu produk.

Melihat permasalahan tersebut, maka diperlukan suatu strategi untuk mengembangkan pengolahan ikan pada indusrti kecil Casheila. Upaya tersebut bertujuan menjadikan industri pengolahan hasil perikanan yang memenuhi syarat kelayakan sehingga menghasilkan produk yang bermutu, aman konsumsi serta sehat dan nyaman bagi pelaku usaha.

Berdasarkan latar belakang masalah yang telah dikemukakan maka peneliti dapat mengidentifikasi rumusan masalah sebagai berikut :

1. Apakah pengembangan usaha CASHEILA layak dilakukan, dilihat dari aspek non finansial dan aspek finansial?

2. Bagaimana sensitivitas perusahaan terhadap perubahan yang terjadi?

\section{Tabel 1. Data Hasil Penjualan Produk Ikan "Casheila"}

\begin{tabular}{lcccccc}
\hline \multirow{2}{*}{ BULAN } & \multicolumn{7}{c}{ TAHUN } \\
\cline { 2 - 7 } & \multicolumn{2}{c}{2015} & & 2016 & & $2017^{*}$ \\
\hline JANUARI & $\mathrm{Rp}$ & 41.500 .000 & $\mathrm{Rp}$ & 54.000 .000 & $\mathrm{Rp}$ & 53.400 .000 \\
\hline FEBRUARI & $\mathrm{Rp}$ & 45.750 .000 & $\mathrm{Rp}$ & 46.200 .000 & $\mathrm{Rp}$ & 62.200 .000 \\
\hline MARET & $\mathrm{Rp}$ & 52.500 .000 & $\mathrm{Rp}$ & 45.750 .000 & $\mathrm{Rp}$ & 54.000 .000 \\
\hline APRIL & $\mathrm{Rp}$ & 38.900 .000 & $\mathrm{Rp}$ & 54.400 .000 & $\mathrm{Rp}$ & 51.400 .000 \\
\hline MEI & $\mathrm{Rp}$ & 44.500 .000 & $\mathrm{Rp}$ & 49.600 .000 & $\mathrm{Rp}$ & 67.600 .000 \\
\hline JUNI & $\mathrm{Rp}$ & 51.000 .000 & $\mathrm{Rp}$ & 63.200 .000 & $\mathrm{Rp}$ & 60.900 .000 \\
\hline JULI & $\mathrm{Rp}$ & 48.750 .000 & $\mathrm{Rp}$ & 49.000 .000 & $\mathrm{Rp}$ & 58.500 .000 \\
\hline AGUSTUS & $\mathrm{Rp}$ & 48.800 .000 & $\mathrm{Rp}$ & 50.100 .000 & $\mathrm{Rp}$ & 61.800 .000 \\
\hline SEPTEMBER & $\mathrm{Rp}$ & 38.000 .000 & $\mathrm{Rp}$ & 47.500 .000 & $\mathrm{Rp}$ & 54.900 .000 \\
\hline OKTOBER & $\mathrm{Rp}$ & 39.600 .000 & $\mathrm{Rp}$ & 51.400 .000 & $\mathrm{Rp}$ & 56.200 .000 \\
\hline NOVEMBER & $\mathrm{Rp}$ & 51.400 .000 & $\mathrm{Rp}$ & 44.550 .000 & $\mathrm{Rp}$ & - \\
\hline DESEMBER & $\mathrm{Rp}$ & 51.600 .000 & $\mathrm{Rp}$ & 45.600 .000 & $\mathrm{Rp}$ & - \\
\hline TOTAL & $\mathrm{Rp}$ & 552.300 .000 & $\mathrm{Rp}$ & 601.300 .000 & $\mathrm{Rp}$ & 580.900 .000 \\
\hline & & & & & &
\end{tabular}




\section{Kajian Literatur}

Menurut Kasmir dan Jakfar (2012:7) studi kelayakan bisnis adalah suatu kegiatan yang mempelajari secara mendalam tentang suatu kegiatan atau usaha yang akan dijalankan, untuk menentukan layak atau tidaknya suatu bisnis dijalankan.

Sementara itu, Sunyoto (2014:7) menyatakan bahwa studi kelayakan bisnis adalah penelitian yang menyangkut berbagai aspek berupa aspek hukum, aspek keuangan, aspek sosial ekonomi dan budaya, aspek pasar dan pemasaran, aspek perilaku konsumen, aspek teknis dan teknologi, aspek sumber daya manusia dan organisasi, dimana semua itu digunakan untuk mengambil keputusan apakah suatu proyek atau bisnis dapat dikerjakan atau tunda bahkan tidak dijalankan.

Studi kelayakan adalah sebuah studi untuk mengkaji secara komprehensif dan mendalam terhadap kelayakan sebuah usaha. Layak atau tidak layak dijalankanya sebuah usaha merujuk pada hasil pembandingan semua faktor ekonomi yang akan dialokasikan kedalam usaha atau bisnis baru dengan hasil pengembaliannya yang akan diperoleh dalam jangka waktu tertentu.

Menurut Rangkuti (2015:8), terdapat banyak pihak yang dapat merasakan manfaat dari studi kelayakan bisnis ini sebagai masukan dalam kegiatan kaji ulang kegiatan usaha, serta memberikan kesepakatan untuk kegiatan usaha ini layak atau tidak dilaksanakan.

studi kelayakan bisnis (SKB). Seperti diketahui, hasil dari suatu studi kelayakan bisnis adalah laporan tertulis. Isi laporan studi kelayakan bisnis menyatakan bahwa suatu rencana bisnis layak direalisasikan. Namun bisa saja terjadi ada pihak-pihak tertentu yang memerlukan laporan tadi sebagai bahan masukan utama dalam rangka mengkaji ulang untuk turut serta menyetujui atau sebaliknya menolak kelayakan laporan tadi sesuai dengan kepentingannya. Mungkin saja terjadi bahwa hasil studi kelayakan yang telah dinyatakan layak ternyata pada akhirnya tidak dilaksanakan. Hal ini, misalnya, dapat disebabkan oleh pengambil keputusan akhir yang menolak karena adanya intervensi pihak lain yang merasa kepentingannya tidak terpenuhi.

Dalam melaksanakan studi kelayakan bisnis, ada beberapa tahapan studi yang hendak dikerjakan. Tahap-tahap dalam pelaksanaan studi kelayakan bisnis secara umum (Danang, 2012:8):

1. Penerapan Ide

Produk yang dibuat haruslah berpotensi untuk di jual dan menguntungkaan. Oleh karena itu, penelitian terhadap kebutuhan pasar dan jenis produk dari proyek harus dilakukan. Penelitian jenis produk dapat dilakukan dengan kriteria-kriteria bahwa sesuatu produk dibuat untuk memenuhi kebutuhan pasar yang masih belum dipenuhi, memenuhi kebutuhan manusia tetapi produk tersebut belum ada, dan untuk mengganti produk yang sudah ada dengan produk yang lain yang mempunyai nilai lebih. Sedangkan mengenai kebutuhan pasar, hasil penelitian yang di harapkan adalah bahwa produk yang akan dihasilkan dapat dijual dipasar yang cukup sehat (permintaan yang cukup baik dalam jangka panjang).

\section{Tahap Penelitian}

Setelah tiga ide proyek dipilih, selanjutnya dilakukan penelitian yang lebih mendalam dengan memakai metode ilmiah. Dimulai dengan mengumpulkan data, lalu mengolah data berdasarkan teori-teori yang relevan, menganalisis dan menginter-presentasikan hasil pengolahan data dengan alat-alat analisis yang sesuai, menyimpulkan hasil sampai pada pekerjaan membuat laporan hasil penelitian tersebut. 
3. Tahap Evaluasi

Ada tiga macam evaluasi. Pertama, mengevaluasi usulan proyek yang akan didirikan. Kedua, mengevaluasi proyek yang sedang dibangun. Dan ketiga, mengevaluasi bisnis yang sudah dioperasionalkan secara rutin. Evaluasi berati membandingkan sesuatu dengan satu atau lebih standar atau kriteria, dimana standar atau kriteria ini dapat bersifat kuantitatif maupun kualitatif. Hal yang dibandingkan dalam evaluasi bisnis adalah seluruh ongkos yang akan ditimbulkan oleh usulan bisnis serta manfaat atau benfit yang diperkirakan akan diperoleh.

4. Tahap Pengurutan Usulan Yang Layak

Jika terdapat lebih dari satu usulan rencana bisnis yang dianggap layak dan terdapat keterbatasan-keterbaatasan yang dimiliki manajemen untuk merelasikan semua rencana

\section{Tahap Rencana Pelaksanaan}

Setelah rencana bisnis dipilih untuk direalisasikan, perlu dibuat rencana kerja kerja pelaksanaan pembangunan proyek. Mulai dari menentukan jenis pekerjaan, jumlah dan kualifikasi tenaga pelaksana, ketersediaan dana dan sumber dana lain, kesiapan manajemen, dan lain-lain.

6. Tahap Pelaksanaan

Setelah semua persiapan yang harus dikerjakan selesai disiapkan, tahap berikutnnya adalah merealisasikan pembangunan proyek tersebut. Kegiatan ini membutuhkan manajemen proyek. Jika proyek selesai dikerjakan, tahap berikutnnya adalah melaksanakan operasional bisnis ini secara rutin. Dalam operasional ini, perlu kajian-kajian untuk mengevaluasi bisnis, yaitu dari fungsional keuangan, pemasaran, produksi / operasi, SDM dan manajemennya agar selalu bekerja secara efektif dan efesien dalam rangka meningkatkan laba perusahaan. Hasil evaluasi dapat dijadikan sebagai feedback bagi perusahaan untuk selalu mengkaji ulang proses bisnis ini secara terus-menerus.

Menurut Danang (2012 : 11) aspek yang terdapat pada studi kelayakan proyek atau bisnis yang terdiri dari berbagai aspek antara lain:

1. Aspek Pasar

Menurut para ahli, pasar merupakan tempat pertemuan antara penjual dan pembeli, atau saling bertemunnya antara kekuatan permintaan dan penawaran untuk membentuk suatu harga. Pendapat ahli yang lain mengatakan bahwa pasar merupakan suatu sekelompok orang yang diorganisasikan untuk melakukan tawar-menawar, sehingga demikian terbentuk harga. Stanton (2002) mengemukakan pengertian yang lain tentang pasar, yakni merupakan system keseluruhan dari kegiatan yang ditujukan untuk merencanakan, menentukan harga, mempromosikan dan mendistribusikan barang dan jasa yang dapat memuaskan kebutuhan kepada pembeli yang ada maupun pembeli potensial. Jadi terdapat tiga faktor utama yang menunjang terjadinya pasar, yaitu orang dengan segala keinginannya, daya belinya, serta tingkah laku dalam pembeliannya.

a. Permintaan

Permintaan dapat diartikan sebagai jumlah barang yang dibutuhkan konsumen yang mempunyai kemampuan untuk membeli pada berbagai tingkat harga. Permintaan yang didukung oleh kekuatan tenaga beli disebut permintaan efektif, sedangkan permintaan yang di dasarkan pada kebutuhan saja disebut sebagai permintaan potensial. Hukum permintaan mengatakan bahwa bila harga suatu barang meningkat, maka kuantitas barang yang diminta akan berkurang, begitu pula sebaliknya, bila harga barang yang diminta menurun, maka kuantitas barang yang diminta menaik (asumsi ceteris paribus). 
b. Penawaran

Penawaran diartikan sebagai berbagai kuantitas barang yang ditawarkan di pasar pada berbagai tingkat harga. Dalam fungsi ini bila harga suatu barang meningkat, maka produsen akan beusaha meningkatkan jumlah barang yang dijualnya. Sampai mana penjual ingin menawarkan barang pada berbagai tingkat harga ditentukan oleh berbagai faktor, diantarannya ialah : harga barang itu sendiri, harga barang lain, ongkos produksi, tingkat teknologi, dan tujuan-tujuan perusahaan.

2. Aspek Pemasaran

Kegiatan perusahan yang bertujuan menjual barang atau jasa yang di produksi perusahaan kepasar. Oleh karena itu, aspek ini bertanggung jawab dalam menentukan ciri-ciri pasar yang akan dipilih. Analisis kelayakan dari aspek ini yang utama dalam hal Penentuan segmen, target, dan posisi produk pada pasarnya. Kajian untuk mengetahui konsumen potensial, seperti perihal sikap, perilaku, serta kepuasaan mereka atas produk.

\section{Aspek Teknis Dan Teknologi}

Aspek teknis merupakan aspek yang berkenaan dengan pengoperasian dan proses pembangunan proyek secara teknis setelah proyek atau bisnis tersebut selesai dibangun atau didirikan. Berdasarkan analisis ini pula dapat diketahui rancangan awal penaksiran biaya investasi termasuk start up cost atau pra operasional proyek yang akan dilaksanakan.

\section{Aspek Manajemen}

Studi aspek manajemen dilaksanakan dua macam. Manajemen saat pembangunan proyek bisnis dan Manajemen saat bisnis di operasionalkan secara rutin. Bahkan terjadi, banyak terjadi, bahwa proyek-proyek bisnis gagal dibangun maupun dioperasionalkan bukan disebkan karena aspek lain, tetapi karena lemahnya manajemen.

a. Aspek Sumber Daya Manusia

Aspek ini membutuhkan daya imajinasi tinggi untuk membayangkan bentuk organisasi apa yang akan dibangun kelak ketika berdiri. Setelah gambaran organisasi terbentuk dengan segala kelengkapannya, selanjutnya dianalisis proses pengadaan sumber daya manusianya untuk menduduki dan memegang bagian dan fungsi organisasi sesuai dengan yang direncanakan.

\section{b. Aspek Sosial}

Analisis sosial dilakukan untuk mengetahui apakah dengan keberadaan proyek memberikan dampak pada suatu wilayah menjadi semakin ramai, lalu lintas semakin lancar, adanya jalur komunikasi, penerangan listrik, pendidikan masyarakat setempat dan lainnya.

Pada proyek di bidang pertanian terdapat empat masalah utama yang mengakibatkan proyek sensitif terhadap perubahan, yaitu:

1. Perubahan Terjadinya Penurunan Penjualan

2. Perubahan Kenaikan Harga Bahan Baku

Usaha Mikro, Kecil dan Menengah (UMKM) memiliki peranan penting dalam perekonomian di Indonesia. UMKM memiliki proporsi sebesar 99,99\% dari total keseluruhan pelau usaha di Indonesia atau sebanyak 56,54 juta unit (LPPI BI, 2015). UMKM telah mampu bertahan ditengah krisis moneter tahun 1998. Hal ini dikarenakan mayoritas UMKM tidak bergantung pada modal besar atau pinjaman dari luar negeri (mata uang asing). 
Undang-Undang Nomor 20 Tahun 2008 menjelaskan bahwa sebuah perusahaan digolongkan sebagai Usaha Mikro, Kecil dan Menengah (UMKM) adalah perusahaan kecil yang dimiliki dan dikelola oleh seseorang atau dimiliki oleh sekelompok kecil orang dengan jumlah kekayaan dan pendapatan tertentu (LPPI BI, 2015).

1. Kriteria Usaha Mikro adalah sebagai berikut :

a. Jenis barang/komoditi tidak selalu tetap; sewaktu-waktu dapat berganti

b. Tempat usaha tidak selalu menetap

c. Belum melakukan administrasi keuangan yang sederhana sekalipun

d. Tidak memisahkan keuangan keluarga dengan keuangan usaha

e. Pengusaha belum memiliki jiwa wirausaha yang memadai

f. Umumnya belum akses kepada perbankan, namun mayoritas telah akses ke Lembaga keuangan non bank

g. Umumnya tidak memiliki izin usaha

h. Memiliki kekayaan bersih paling banyak Rp. 50.000.000,00 (lima puluh juta rupiah) tidak termasuk tanah dan bangunan tempat usaha.

i. Memiliki hasil penjualan tahunan paling banyak Rp. 300.000.000,00 (tiga ratus juta rupiah).

2. Kriteria Usaha Kecil adalah sebagai berikut:

a. Jenis barang/komoditi umumnya sudah tetap

b. Lokasi/tempat usaha umumnya sudah menetap

c. Pada umumnya sudah melakukan administrasi keuangan walaupun masih sederhana

d. Telah membuat neraca usaha

e. Umumnya telah memiliki izin usaha dan NPWP

f. Pengusaha memiliki pengalaman dalam berwirausaha

g. Sebagian besar sudah akses ke perbankan dalam keperluan modal

h. Memiliki kekayaan bersih lebih dari Rp. 50.000.000,00 (lima puluh juta rupiah) sampai dengan paling banyak Rp. 500.000.000,00 (lima ratus juta rupiah) tidak termasuk tanah dan bangunan tempat usaha.

i. Memiliki hasil penjualan tahunan lebih dari Rp. 300.000.000,00 (tiga ratus juta rupiah) sampai dengan paling banyak Rp. 2.500.000.000,00 (dua milyar lima ratus juta rupiah).

3. Kriteria Usaha Menengah adalah sebagai berikut :

a. Memiliki manajemen dan organisasi yang lebih baik, dengan pemberian tugas yang jelas

b. Telah melakukan manajemen keuangan dengan menerapkan system akuntasi dengan teratur sehingga memudahkan untuk auditing

c. Telah melakukan aturan atau pengelolaan dan organisasi perburuhan

d. Telah memiliki persyaratan legalitas

e. Telah memiliki akses kepada sumber-sumber pendanaan perbankan

f. Pada umumnya telah memiliki sumber daya manusia yang terlatih dan terdidik

g. Memiliki kekayaan bersih lebih dari Rp. 500.000.000,00 (lima ratus juta rupiah) sampai dengan paling banyak Rp. 10.000.000.000,00 (sepuluh milyar rupiah) tidak termasuk tanah dan bangunan tempat usaha.

h. memiliki hasil penjualan tahunan lebih dari Rp. 2.500.000.000,00 (dua milyar lima ratus juta rupiah) sampai dengan paling banyak Rp. 50.000.000.000,00 (lima puluh milyar rupiah).

Menurut kategori Biro Pusat Statistik (BPS), usaha kecil identik dengan industri kecil dan industri rumah tangga. BPS mengklasifikasikan industri berdasarkan jumlah pekerjanya, 
yaitu : (1) industri rumah tangga dengan pekerja 1-4 orang; (2) industri kecil dengan pekerja 5-19 orang; (3) industri menengah dengan pekerja 20-99 orang; (4) industri besar dengan pekerja 100 orang atau lebih.

Industri adalah suatu usaha atau kegiatan pengolahan bahan mentah atau barang setengah jadi menjadi barang jadi barang jadi yang memiliki nilai tambah untuk mendapatkan keuntungan. Hasil industri tidak hanya berupa barang, tetapi juga dalam bentuk jasa. industri sebagai suatu sistem terdiri dari unsur fisik dan dan unsur perilaku manusia. Unsur fisik yang mendukung proses industri adalah komponen tempat meliputi pula kondisinya, peralatan, bahan baku atau bahan mentah dan beberapa hal yang memerlukan sumber energi, sedangkan unsur perilaku manusia meliputi komponen tenaga kerja, ketrampilan tradisi, transportasi dan komunikasi serta keadaan politik dan pasar.

Untuk mengetahui pengembangan usaha yang dijalankan Casheila, dilakukan analisis kelayakan dengan mengkaji aspek-aspek kelayakan usaha seperti aspek finansial dan nonfinansial yang dapat dilihat dari aspek pasar, teknis, finansial, manajemen dan sosial. Dari aspek finansial dilakukan analisis mengenai PP, NPV, PI,IRR, dan analisis Sensitivitas. Dari hasil penelitian ini diharapkan dapat memberikan rekomendasi terhadap pelaksanaan usaha yang dijalankan oleh Casheila. Ditunjukan pada Gambar 1.

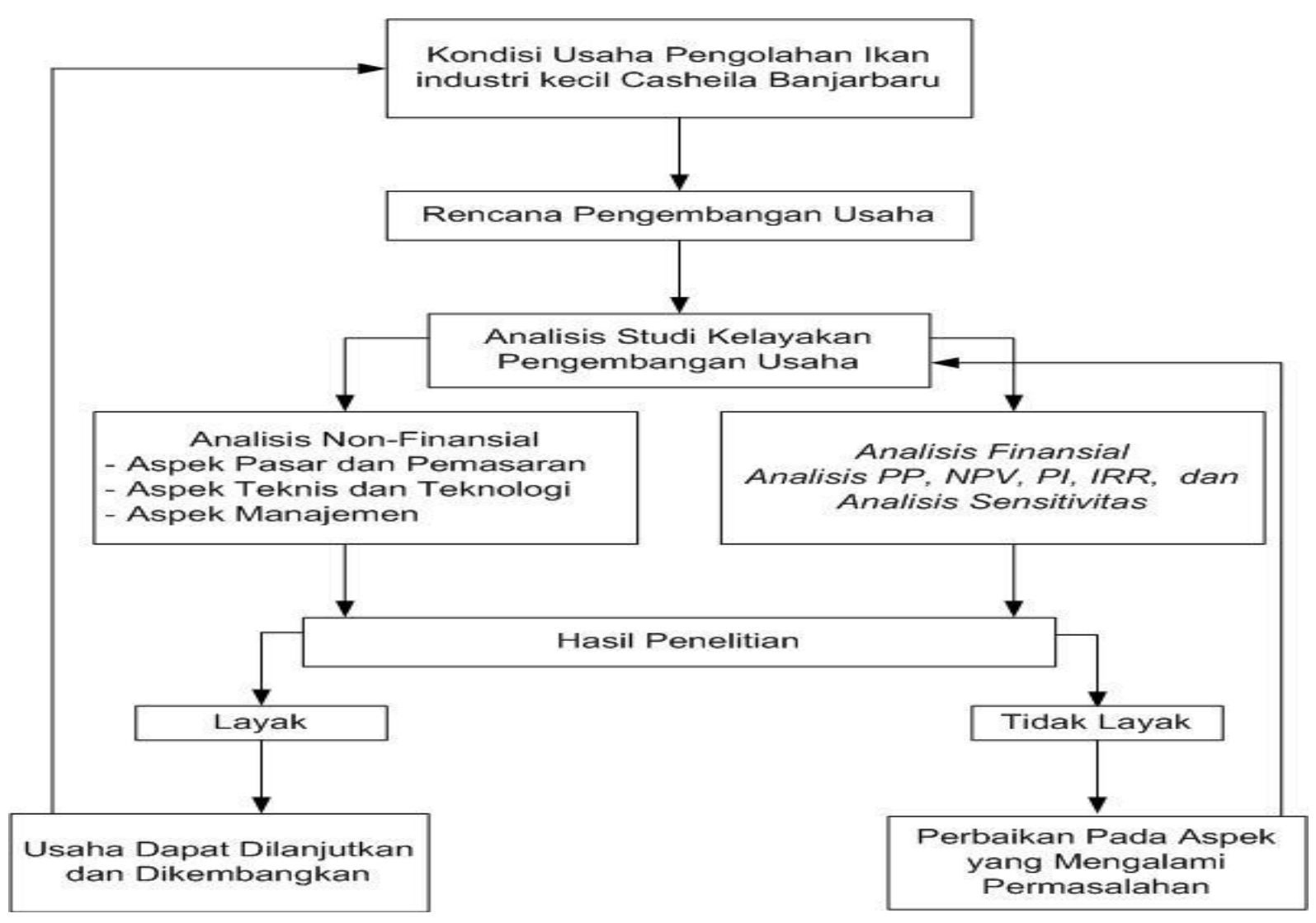

\section{Gambar 1 : Kerangka Berfikir Pnelitian}

\section{Metode Penelitian}

Data dalam penelitian ini adalah data kuantitatif dan kualitatif. Data kuantitatif adalah data berbentuk angka yang memiliki satuan hitung dan dihitung atau diukur seperti jumlah produksi dan penjualan, harga jual, biaya produksi dan biaya lain-lain. Sedangkan data kualitatif adalah data yang tidak berbentuk angka berupa keterangan atau informasi seperti informasi tentang aspek pasar, aspek teknis, aspek sosial, profil perusahaan, dll. 
Sumber data yang digunakan dalam penelitian ini adalah data primer dan data sekunder. Data primer merupakan data hasil wawancara, maupun observasi langsung di lapangan. Sedangkan data sekunder diperoleh dari hasil laporan perusahaan, artikel, studi serta data lembaga yang terkait penelitian ini

Pengumpulan data dilakukan dengan nterview atau wawancara dengan pemilik dan pengelola dari industri mengenai data-data yang akan peneliti analisis, berkaitan dengan kelayakan bisnis. Metode dokumentasi merupakan pengumpulan data baik angka maupun keterangan secara tertulis. metode dokumentasi adalah suatu cara untuk memperoleh data atau informasi tentang hal-hal yang ada kaitannya dengan penelitian, dengan jalan melihat kembali sumber tertulis yang lalu baik berupa angka atau keterangan.

Teknik analisis yang digunakan pada penelitian ini dilihat dari aspek non finansial dan aspek finansial. Analisis Non-Finansial.

1. Aspek Non Finansial

a. Aspek Pasar dan Pemasaran yaitu untuk mendapatkan gambaran kelayakan terhadap permintaan potensial atau pengguna produk yang dihasilkan, kemungkinan adanya persaingan, serta perkiraan penjualan yang dapat dicapai.

b. Aspek Teknis dan Teknologi dimaksudkan untuk mendapatkan gambaran kelayakan terhadap penentuan kapasitas, jenis teknologi yang paling cocok, lokasi yang paling menguntungkan dan pemenuhan ketenagaan untuk mengelola peralatan.

c. Aspek Manajemen berfungsi untuk aktivitas-aktivitas perencanaan, pengorganisasian, pelaksanaan dan pengendalian. Bentuk struktur organisasi, dan pembagian kerja karyawan.

2. Analisis Finansial

a. NPV (Net Present Value) atau Nilai sekarang bersih adalah selisih antara nilai sekarang investasi dengan nilai sekarang penerimaan kas bersih di masa yang akan datang. Net Present Value (NPV) merupakan selisih antara Present value benefit dan present value biaya. Untuk mencari NVP digunakan Rumus:

$$
N P V=\frac{\sum_{i=0}^{\mathrm{n}}\left(\mathrm{B}_{\mathrm{t}}-\mathrm{C}_{\mathrm{t}}\right)}{(1+\mathrm{i})^{\mathrm{t}}}
$$

Keterangan:

$$
\begin{array}{ll}
\mathrm{Bt} & =\text { Penerimaan (benefit) tahun ke-t } \\
\mathrm{Ct} & =\text { Biaya }(\text { Cost }) \text { tahun ke-t } \\
\mathrm{I} & =\text { Tingkat suku bunga yang berlaku } \\
\mathrm{t} & =\text { Lamanya waktu / umur investasi }
\end{array}
$$

Jika NVP > 0 maka usaha tersebut menguntungkan.

Jika NVP < 0 maka usaha tersebut tidak menguntungkan.

Jika NVP = 0 maka usaha tersebut berada pada Break Even Point (BEP).

b. IRR (Internal Rate of Return) adalah tingkat diskonto atau discount rate yang menyamakan present value aliran kas bersih dengan present value invetasi. Internal Rate of Return (IRR) menunjukkan kemampuan suatu usaha untuk menghasilkan keuntungan atau Return yang dapat dicapainya. Untuk menentukan IRR digunakan Rumus:

$$
\operatorname{IRR}=i_{1} \frac{N P V_{1}}{\left(N P V_{1}-N P V_{2}\right)}\left(i_{2}-i_{1}\right)
$$


Keterangan:

NVP1 = NPV yang diperoleh dari discount factor 1

NVP2 = NPV yang diperoleh dari discount factor 2

i1 = tingkat discount factor 1

i2 = tingkat discount factor 2

Jika hasil analisa menunjukkan IRR > tingkat suku bunga bank, maka usaha itu menguntungkan, maka dapat disimpulkan usaha tersebut dapat diteruskan.

c. PP (Payback Period) merupakan jangka waktu tertentu yang dibutuhkan untuk mengembalikan atau menutup pengeluaran modal awalnya dengan aliran kas masuk yang diperoleh selama tahun-tahun operasi di masa datang. PP yaitu perbandingan antara keuntungan dengan biaya total yang dikeluarkan. Rumus yang digunakan untuk menghitung payback period (PP) adalah sebagai berikut:

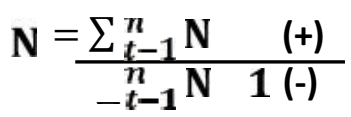

Keterangan:

$\mathrm{NB}(+)=$ Net Benefit bernilai positif

NB (-) = Net Benefi bernilai negatif

$\mathrm{n} \quad=$ Umur ekonomis

d. Indeks Keuntungan (Profitability Index). Indeks profitabilitas adalah rasio dari PV total penerimaan kas masa datang terhadap investasi awal, atau PV/I. Indeks ini digunakan sebagai sarana untuk membuat peringkat proyek dalam urutan daya tarik yang semakin menurun dengan rumus:

$\mathrm{PI}=1+(\mathrm{NPV}+\mathrm{ICO})$

Keterangan :

PI = Profitability Index

NPV = Net Present Value

ICO = Initial Cash Flow (biaya investasi)

Dengan ketentuan jika PI > 1, maka usaha layak dijalankan, dan jika PI $<1$, maka tidak layak dijalankan.

3. Analisis sensitivitas atau laju kepekaan adalah suatu kegiatan menganalisis kembali suatu proyek untuk melihat apakah yang akan terjadi pada proyek tersebut bila suatu proyek tidak berjalan sesuai rencana.

\section{Hasil Penelitian dan Pembahasan}

Usaha Pengolahan Ikan Pada Industri Kecil Casheila Banjarbaru merupakan industri rumah tangga yang didirikan perseorangan. Usaha Casheila Food mulai dirintis pada akhir tahun 2014 awal didirikannya industri ini dikarenakan untuk menambah penghasilan dan membantu perekonomian, yang didasari pengamatan bahwa usaha pengolahan ikan memiliki prospek cerah kedepannya dan didukung beberapa program pemerintah. Bermodalkan 
keinginan dan pengalaman beberapa kegiatan pelatihan yang pernah diikuti untuk memulai usaha, mulai dengan mengolah ikan sepat sambal.

Industri casheila merupakan industri kecil yang dikerjakan dengan manajemen sederhana dengan karyawan yang berasal dari warga sekitar. Beberapa produk yang di produksi salah satunnya ikan sepat sambal, ikan sepat sambal madu, dan kerupuk ikan gabus. Awal memproduksi ikan sepat menggunakan bahan dan cara sederhana belum menggunakan mesin seperti saat ini. Dengan berjalannya waktu industri casheila mengajukan proposal bantuan dari pemerintah daerah berupa pengadaan peralatan dengan tujuan untuk mempermudah proses produksi, meningkatkan kapasitas produksi, dan efesiensi tenaga kerja.

Analisis kelayakan usaha pengolahan ikan pada industri Casheila dapat dilihat dari aspek:

1. Aspek Non Finansial

a. Aspek Pasar dan Pemasaran

Bentuk pasar produsen untuk industri Casehila adalah pasar monopolistik. Pasar konsumen yang dipilih adalah penjualan melalui distributor dan penjualan langsung (direct selling), karena industri Casheila memiliki tempat (Toko) yang tetap di area sentra oleh-oleh. Yang ingin dicapai oleh industri Casheila adalah penduduk Wilayah Kalimantan Selatan, semua Kalangan, terutama untuk masyarakat yang praktis dan instan sebagai cemilan, lauk pauk, dan sebagai oleh-oleh. Saluran distribusi produk Casheila dilakukan secara langsung untuk wilayah Banjarbaru, Martapura, Kandangan dititipkan ditoko-toko dan pusat oleh-oleh di wilayah Kalimantan Selatan.

b. Aspek Teknis dan Teknologi

Teknologi adalah pengembangan dan aplikasi dari alat, mesin, material dan proses yang menolong manusia menyelesaikan masalahnya. Berdasarkan penelitian, teknologi yang digunakan pada industri casheila adalah sebagai berikut:

- Mesin sepiner, mesin ini digunakan untuk menghilangkan kadar minyak dalam ikan sepat,

- Saler (alat pengemas) alat ini digunakan dalam proses pengemasan produk ikan,

- Mesin oven, mesin ini digunakan untuk mengoven ikan setelah hilangnya kadar minyak dalam ikan.

Industri Casheila telah memiliki legalitas usaha yaitu dengan telah memiliki surat-surat penjanjian yang dibutuhkan oleh suatu usaha, seperti Surat Ijin Usaha, dan juga produk dari industri casheila mendapat sertifikat kesehatan produksi pangan industri rumah tangga (SSP-IRT) dengan No: 5026372020410-19. Sedangkan surat keterangan Halal dari LPPOM-MUI dengan No: 28031001520315. Lahan dan lokasi yang dipergunakan untuk kegiatan produksi oleh industri Casheila telah memiliki legalitas domisili yang jelas. Karena dengan dimilikinya surat keterangan domisili industri dengan No : 192 / SKU / - EKO / KGP/ 2013.

c. Aspek Sumber Daya Manusia

Industri kecil casheila menggunakan struktur sederhana yang terdiri dari Pembina, ketua, sekretaris, bendahara, dan anggota.

2. Aspek Finansial

Analisis kriteria kelayakan aspek keuangan bertujuan untuk menentukan kelayakan suatu bisnis atau usaha dari sisi finansial dengan memperhitungkan nilai waktu dari uang (Time Value Of Money). Perhitungan kriteria investasi menggunakan bantuan metode Discounted Cash Flow, dimana seluruh manfaat dan biaya untuk setiap tahun diskonto dengan 
Discount Factor (DF) untuk mendapatkan nilai masa kini dari manfaat dan biaya agar dapat dibandingkan.

a. Payback pariode (PP)

Periode pengambilan adalah jangka waktu yang diperlukan untuk mengembalikan modal investasi. PP dibagi menjadi 2 yaitu Simple Payback Period (tanpa memperhitungkan suku bunga) dan Discounted Payback Period (memperhitungkan suku bunga). Perhitungan PP dapat dilihat pada Tabel 2.

Tabel 2. Hasil Perhitungan Payback Period

\begin{tabular}{|c|c|}
\hline Uraian & Perhitungan PP \\
\hline Investasi & Rp 300.605.000 \\
\hline Arus Kas Tahun 2015 & Rp 298.928.000 \\
\hline Sisa Investasi Tahun II & $\begin{array}{ll}\mathrm{Rp} & 1.677 .000 \\
\end{array}$ \\
\hline Arus Kas Tahun 2016 & $\mathrm{Rp} 316.373 .000$ \\
\hline Sisa Investasi Tahun III & $\operatorname{Rp}(314.696 .000)$ \\
\hline Arus Kas 2017 & $\mathrm{Rp} 329.765 .000$ \\
\hline
\end{tabular}

Sisa investasi Tahun ke dua tertutup oleh proceed tahun kedua sebesar Rp.316.373.000 sehingga sisa waktu payback adalah:

Payback Period

(1 Tahun)

$$
\begin{array}{cc}
= & \frac{\operatorname{Rp}}{\operatorname{Rp~} 316.677 .000} \\
= & 0,063608462 \\
= & 0,12 \\
& 1 \text { Tahun 1 Bulan }
\end{array}
$$

b. Net present value (NPV)

Net Present Value atau nilai sekarang bersih adalah selisih antara total present value arus kas masuk dengan total present value arus kas keluar. Nilai NPV pada kelayakan bisnis industri Casheila dapat dilihat pada Tabel 3.

Tabel 3. Hasil Perhitungan NPV dalam Kondisi Normal

\begin{tabular}{cccc}
\hline Tahun & $\begin{array}{c}\text { Net Cash Flow } \\
(\text { Rupiah) }\end{array}$ & $\begin{array}{c}\text { DF } \\
14 \%\end{array}$ & $\begin{array}{c}\text { PV Cash Flow } \\
\text { (Rupiah_ }\end{array}$ \\
\hline 2015 & 298.928 .000 & 0,877 & 262.219 .642 \\
\hline 2016 & 316.373 .000 & 0,769 & 243.449 .024 \\
\hline 2017 & 329.765 .000 & 0,670 & 222.591 .375 \\
\hline 2018 & 324.264 .000 & 0,592 & 191.996 .714 \\
\hline 2019 & 314.028 .000 & 0,519 & 163.106 .143 \\
\hline 2020 & 333.864 .000 & 0,455 & 152.108 .438 \\
\hline 2021 & 327.264 .000 & 0,399 & 130.774 .694 \\
\hline 2022 & 359.256 .000 & 0,350 & 125.955 .154 \\
\hline \multicolumn{2}{l}{ Total PV Cash Flow } & & 1.492 .201 .184 \\
\hline \multicolumn{2}{l}{ Total PV Investasi } & & 1.191 .596 .184 \\
\hline
\end{tabular}


Nilai NPV pada industri Casheila adalah Rp.1.191.596.184,-. Hal ini menunjukan bahwa pengembangan usaha layak dijalankan karena NPV yang dihasilkan lebih besar dari satu (NPV > 1).

c. Profitability index (PI)

Profitability Index merupakan perbandingan antara present value dari rencana penerimaan kas bersih masa yang akan datang dengan present value dari investasi. Hasil Profitability index (PI) dapat dilihat pada Tabel 4.

Tabel 4. Hasil Perhitungan PI Dalam Kondisi Normal

\begin{tabular}{|c|c|c|c|}
\hline Tahun & Net Cash Flow & $\mathrm{DF}=14 \%$ & PV Cash Flow \\
\hline 2015 & Rp 298.928.000 & 0,8772 & Rp 262.219.642 \\
\hline 2016 & Rp 316.373.000 & 0,7695 & Rp 243.449.024 \\
\hline 2017 & Rp 329.765.000 & 0,6750 & $\operatorname{Rp} 222.591 .375$ \\
\hline 2018 & Rp 324.264.000 & 0,5921 & Rp 191.996.714 \\
\hline 2019 & Rp 314.028.000 & 0,5194 & Rp 163.106.143 \\
\hline 2020 & Rp 333.864.000 & 0,4556 & Rp 152.108.438 \\
\hline 2021 & Rp 327.264.000 & 0,3996 & Rp 130.774.694 \\
\hline 2022 & Rp 359.256.000 & 0,3506 & Rp 125.955.154 \\
\hline \multicolumn{2}{|c|}{ Total PV Cash Flow } & & Rp 1.492.201.184 \\
\hline \multicolumn{2}{|c|}{ Total PV Investasi } & & $\mathrm{Rp} \quad 300.605 .000$ \\
\hline \multicolumn{2}{|c|}{ PI } & & 4,963993227 \\
\hline \multicolumn{3}{|l|}{ PI } & \\
\hline
\end{tabular}

Hasil perhitungan menunjukan nilai PI pada kelayakan usaha industri Casheila sebesar 4,96. Hal ini menunjukan usaha industri Casheila layak dilaksanakan karena PI >1.

Tabel 5. Hasil Perhitungan IRR dalam Kondisi Normal Suku Bunga $14 \%$ dan $16 \%$

\begin{tabular}{ccccccccc}
\hline Tahun & Net Cash Flow & DF $=14 \%$ & \multicolumn{2}{c}{ PV Cash Flow } & DF=16\% & \multicolumn{2}{c}{ PV Cash Flow } \\
\hline 1 & & 2 & 3 & & $4=2 * 3$ & 5 & & $6=2 * 5$ \\
\hline 2015 & $\mathrm{Rp}$ & 298.928 .000 & 0,8772 & $\mathrm{Rp}$ & 262.219 .642 & 0,8621 & $\mathrm{Rp}$ & 257.705 .829 \\
\hline 2016 & $\mathrm{Rp}$ & 316.373 .000 & 0,7695 & $\mathrm{Rp}$ & 243.449 .024 & 0,7432 & $\mathrm{Rp}$ & 235.128 .414 \\
\hline 2017 & $\mathrm{Rp}$ & 329.765 .000 & 0,6750 & $\mathrm{Rp}$ & 222.591 .375 & 0,6407 & $\mathrm{Rp}$ & 211.280 .436 \\
\hline 2018 & $\mathrm{Rp}$ & 324.264 .000 & 0,5921 & $\mathrm{Rp}$ & 191.996 .714 & 0,5523 & $\mathrm{Rp}$ & 179.091 .007 \\
\hline 2019 & $\mathrm{Rp}$ & 314.028 .000 & 0,5194 & $\mathrm{Rp}$ & 163.106 .143 & 0,4761 & $\mathrm{Rp}$ & 149.508 .731 \\
\hline 2020 & $\mathrm{Rp}$ & 333.864 .000 & 0,4556 & $\mathrm{Rp}$ & 152.108 .438 & 0,4104 & $\mathrm{Rp}$ & 137.017 .786 \\
\hline 2021 & $\mathrm{Rp}$ & 327.264 .000 & 0,3996 & $\mathrm{Rp}$ & 130.774 .694 & 0,3538 & $\mathrm{Rp}$ & 115.786 .003 \\
\hline 2022 & $\mathrm{Rp} 359.256 .000$ & 0,3506 & $\mathrm{Rp}$ & 125.955 .154 & 0,3050 & $\mathrm{Rp}$ & 109.573 .080 \\
\hline \multicolumn{3}{c}{ Total } & $\mathrm{Rp} 1.492 .201 .184$ & & $\mathrm{Rp} 1.395 .091 .285$ \\
\hline
\end{tabular}

d. Internal rate of retrun (IRR)

Internal rate of retrun (IRR) adalah indikator tingkat efesiensi suatu rencana investasi dapat diterima. Besarnya IRR ini tidak ditentukan secara langsung dan harus dengan cara coba-coba untuk mendapatkan nilai NPV Nilai IRR pada industri Casheila dapat dilihat dari Tabel 6. Dengan perhitungan nilai sebagai berikut:

$$
\begin{array}{ll}
\text { NPV untuk } \\
\begin{array}{ll}
\mathrm{DF}=14 \% \\
\end{array} & =\frac{\mathrm{Rp} 1.492 .201 .184}{\operatorname{Rp} 300.605 .000}- \\
& =\operatorname{Rp~} 1.191 .596 .184
\end{array}
$$




$$
\begin{aligned}
& \text { NPV untuk } \\
& =\frac{R p 1.395 .091 .285}{\operatorname{Rp~} 300.605 .000}- \\
& =\quad \operatorname{Rp} 1.094 .486 .285 \\
& \begin{aligned}
\mathrm{IRR} & =(16 \%-14 \%) \frac{\mathrm{NPV} 1}{\mathrm{NPV} 1-\mathrm{NPV} 2} \\
& =2 \% \quad \frac{\mathrm{Rp} 1.191 .596 .184}{\mathrm{Rp} 1.191 .596 .184-\mathrm{Rp} 1.094 .486 .285}
\end{aligned} \\
& =(2 \%) \quad \frac{R p 1.191 .596 .184}{R p \quad 97.109 .899} \\
& =(2 \%) 12,27059436 \\
& =24,54 \%
\end{aligned}
$$

Nilai IRR pada kelayakan usaha industri Casheila adalah 24,54\% > 14,08\% dari segi IRR usaha pengembangan ini layak dilaksanakan.

Analisis kriteria kelayakan bisnis yang digunakan pada industri Casheila terdiri dari Payback Periode (PP), Net Present Value (NPV), Profitability Index (PI) atau Benefit Cost Ratio B/C, dan Internal Rate Return (IRR). Hasil perhitungan dari analisis kriteria investasi dapat dilihat pada Tabel 6.

Tabel 6. Nilai Kelayakan Usaha Industri Casheila

\begin{tabular}{lr}
\multicolumn{1}{c}{ Kriteria Kelayakan } & \multicolumn{2}{c}{ Nilai } \\
\hline Payback Periode (PP) & 1 Tahun 1 Bulan \\
\hline Net Present Value (NPV) & Rp1.191.596.184 \\
\hline Profitability Index (PI) & 4,96 \\
\hline Internal Rate Of Retrun (IRR) & $24,54 \%$ \\
\hline
\end{tabular}

Berdasarkan hasil perhitungan baik menggunakan metode Payback Period, Net Present Value, Profitability Index maupun Internal Rate of Return, Usaha Casheila layak dijalankan.

3. Analisis Sensitivitas

Analisis sensitivitas dimaksudkan untuk melihat hasil analisis kelayakan usaha yang telah dilakukan terhadap kemungkinan-kemungkinan yang akan terjadi dimasa yang akan datang. Dalam analisis sensitivitas ini menggunakan asumsi penurunan produksi ikan sepat sambal sebesar $10 \%$ dan terjadinya kenaikan harga input bahan baku sebesar $20 \%$. Hasil analisis sensitivitas pada industri casheila dapat dilihat pada Tabel 7, 8, 9

Perhitungan sensitivitas pada kondisi normal dengan discount factors menggunakan tingkat suku bunga $14 \%$, jika pada saat suku bunga menurun menggunakan suku bunga $12 \%$ dan pada saat suku bunga naik $16 \%$. Dengan nilai NPV normal DF12\% Rp.248.264.000, DF14\% Rp. 231.572 .000, dan DF16\% Rp.216.557.000. denagn kondisi penurunan produksi sehingga menyebabkan turunnya penjualan sebesar $10 \%$. Dengan 
menghasilkan Nilai NPV DF 12\% Rp.88.228.000 dan DF 14\% Rp.82.352.000. dengan kenaikan harga bahan baku menyebabkan kenaikan biaya produksi sebesar $20 \%$. Dengan perolehan nilai NPV DF 14\% Rp.97.244.000 sedangkan NPV DF 16\% memperoleh Rp.90.630.000.

Tabel 7. Perhitungan Nilai NPV Pada Kondisi Normal

\begin{tabular}{|c|c|c|c|c|c|c|c|c|c|}
\hline \multirow{3}{*}{ Tahun } & \multirow{2}{*}{\multicolumn{3}{|c|}{ Discount Factors }} & \multicolumn{6}{|c|}{$\begin{array}{c}\text { Nilai NPV untuk Perhitungan awal } \\
\text { (Dalam Ribuan Rupiah) }\end{array}$} \\
\hline & & & & \multirow{2}{*}{ Total } & \multirow{2}{*}{$\begin{array}{l}\text { Total } \\
\text { Biaya }\end{array}$} & \multirow{2}{*}{ Selisih } & \multirow{2}{*}{ NPV } & \multirow{2}{*}{$\begin{array}{l}\mathrm{NPV} \\
14 \%\end{array}$} & \multirow{2}{*}{$\begin{array}{l}\text { NPV } \\
16 \%\end{array}$} \\
\hline & $12 \%$ & $14 \%$ & $16 \%$ & & & & & & \\
\hline & 1 & 2 & 3 & 4 & 5 & $6=4-5$ & $7=1 * 6$ & $8=2 * 6$ & $9=3 * 6$ \\
\hline 2015 & 0,8929 & 0,8772 & 0,8621 & 298,928 & 253,372 & 45,556 & 40,677 & 39,962 & 39,274 \\
\hline 2016 & 0,7972 & 0,7695 & 0,7432 & 316,373 & 284,927 & 31,446 & 25,069 & 24,198 & 23,371 \\
\hline 2017 & 0,7118 & 0,6750 & 0,6407 & 329,765 & 251,135 & 78,63 & 55,969 & 53,075 & 50,378 \\
\hline 2018 & 0,6355 & 0,5921 & 0,5523 & 324,264 & 267,336 & 56,928 & 36,178 & 33,707 & 31,441 \\
\hline 2019 & 0,5674 & 0,5194 & 0,4761 & 314,028 & 279,972 & 34,056 & 19,323 & 17,689 & 16,214 \\
\hline 2020 & 0,5066 & 0,4556 & 0,4104 & 333,864 & 270,336 & 63,528 & 32,183 & 28,943 & 26,072 \\
\hline 2021 & 0,4523 & 0,3996 & 0,3538 & 327,264 & 289,836 & 37,428 & 16,929 & 14,956 & 13,242 \\
\hline \multirow[t]{2}{*}{2022} & 0,4039 & 0,3506 & 0,3050 & 359,256 & 304,944 & 54,312 & 21,937 & 19,042 & 16,565 \\
\hline & & & & & Nilai NPV & & 248,264 & 231,572 & 216,557 \\
\hline
\end{tabular}

Tabel 8. Analisis Sentivitas Dengan Penurunan Penjualan Sebesar 10\%

\begin{tabular}{|c|c|c|c|c|c|c|c|}
\hline \multirow{2}{*}{ Tahun } & \multicolumn{2}{|c|}{ Discount Factors } & \multicolumn{5}{|c|}{$\frac{\text { Nilai NPV untuk Perhitungan awal }}{\text { (Dalam Ribuan Rupiah) }}$} \\
\hline & $12 \%$ & $14 \%$ & Total & Total Biaya & Selisih & NPV $12 \%$ & NPV $14 \%$ \\
\hline 1 & 2 & 3 & 4 & 5 & $6=4-5$ & $7=2 * 6$ & $8=3 * 6$ \\
\hline 2015 & 0,8929 & 0,8772 & 269,035 & 253,372 & 15,663 & 13,986 & 13,74 \\
\hline 2016 & 0,7972 & 0,7695 & 284,736 & 284,927 & $-0,191$ & $-0,153$ & $-0,147$ \\
\hline 2017 & 0,7118 & 0,6750 & 296,789 & 251,135 & 45,654 & 32,496 & 30,816 \\
\hline 2018 & 0,6355 & 0,5921 & 291,838 & 267,336 & 24,502 & 15,571 & 14,507 \\
\hline 2019 & 0,5674 & 0,5194 & 282,625 & 279,972 & 2,653 & 1,505 & 1,378 \\
\hline 2020 & 0,5066 & 0,4556 & 300,478 & 270,336 & 30,142 & 15,27 & 13,733 \\
\hline 2021 & 0,4523 & 0,3996 & 294,538 & 289,836 & 4,702 & 2,127 & 1,879 \\
\hline \multirow[t]{2}{*}{2022} & 0,4039 & 0,3506 & 323,33 & 304,944 & 18,386 & 7,426 & 6,446 \\
\hline & & & & Nilai NPV & & 88,228 & 82,352 \\
\hline
\end{tabular}

Tabel 9. Analisis Sentivitas Dengan Kenaikan Biaya Produksi Sebesar 20\%

\begin{tabular}{|c|c|c|c|c|c|c|c|}
\hline \multirow{2}{*}{ Tahun } & \multicolumn{2}{|c|}{ Discount Factors } & \multicolumn{5}{|c|}{$\begin{array}{c}\text { Nilai NPV untuk Perhitungan awal } \\
\text { (Dalam Ribuan Rupiah) }\end{array}$} \\
\hline & $14 \%$ & $16 \%$ & Total & Total Biaya & Selisih & NPV $14 \%$ & NPV $16 \%$ \\
\hline 1 & 2 & 3 & 4 & 5 & $6=4-5$ & $7=2 * 6$ & $8=3 * 6$ \\
\hline 2015 & 0,8772 & 0,8621 & 298,928 & 281,772 & 17,156 & 15,049 & 14,79 \\
\hline 2016 & 0,7695 & 0,7432 & 316,373 & 318,227 & $-1,854$ & $-1,427$ & $-1,378$ \\
\hline 2017 & 0,6750 & 0,6407 & 329,765 & 280,935 & 48,83 & 32,96 & 31,285 \\
\hline 2018 & 0,5921 & 0,5523 & 324,264 & 293,736 & 30,528 & 18,076 & 16,861 \\
\hline 2019 & 0,5194 & 0,4761 & 314,028 & 308,892 & 5,136 & 2,668 & 2,445 \\
\hline 2020 & 0,4556 & 0,4104 & 333,864 & 294,936 & 38,928 & 17,736 & 15,976 \\
\hline 2021 & 0,3996 & 0,3538 & 327,264 & 318,636 & 8,628 & 3,448 & 3,053 \\
\hline \multirow[t]{2}{*}{2022} & 0,3506 & 0,3050 & 359,256 & 334,344 & 24,912 & 8,734 & 7,598 \\
\hline & & & & Nilai NPV & & 97,244 & 90,63 \\
\hline
\end{tabular}

Perhitungan sensitivitas dengan kenaikan harga bahan baku menyebabkan kenaikan biaya produksi sebesar 20\%. Dengan perolehan nilai NPV tingkat suku bunga $14 \%$ 
Rp.97.244.000 sedangkan dengan tingkat suku bunga naik sebesar 16\% memperoleh Rp.90.630.000.

Berdasarkan Tabel 7, Tabel 8, dan Tabel 9 dapat diperoleh nilai NPV dan IRR pada kondisi normal dan dua kondisi yang diukur sensitivitasnya karena penurunan produksi dan kenaikan harga bahan baku.

a. Perbandingan NPV $(i=14 \%)$

- Hasil perhitungan 1 pada kondisi normal : Rp 248.264000

- Hasil perhitungan pada produksi turun $10 \%$ : Rp 88.228.000

- Hasil perhitungan kenaikan bahan baku 20\% : Rp 97.244.000

-

b. Perbandingan IRR

Hasil Perhitungan Pada Kondisi Normal

$$
\begin{aligned}
& =14 \%+\frac{\mathrm{Rp} 248.264 .000}{\operatorname{Rp} 248.264 .000-\operatorname{Rp} 216.557 .000} \times 16 \%-12 \% \\
& =14 \%+\frac{\mathrm{Rp} 248.264 .000}{\operatorname{Rp} 31.707 .000} \\
& =14 \%+7,829942915 \times 4 \% \\
& =14 \%+0,313197717 \\
& =45 \%
\end{aligned}
$$

Hasil perhitungan pada kondisi produksi turun $10 \%$

$$
\begin{aligned}
& =14 \%+\frac{\operatorname{Rp} 88.228 .000}{\mathrm{Rp} 88.228 .000-\mathrm{Rp} 82.352 .000} \times 14 \%-12 \% \\
& =14 \%+\frac{\operatorname{Rp} 88.228 .000}{\operatorname{Rp} 5.876 .000} \times 2 \% \\
& =14 \%+15,01497617 \times 2 \% \\
& =14 \%+0,300299523 \\
& =44 \%
\end{aligned}
$$

Hasil Perhitungan pada kenaikan biaya bahan baku sebesar $20 \%$

$$
\begin{aligned}
& =14 \%+\frac{\operatorname{Rp} 97.244 .000}{\mathrm{Rp} 97.244 .000-\operatorname{Rp} 90.630 .000} \times 16 \%-14 \% \\
& =14 \%+\frac{\operatorname{Rp} 97.244 .000}{\operatorname{Rp} 6.614 .000} \times 2 \% \\
& =14 \%+14,70275174 \times 2 \% \\
& =14 \%+0,294055035 \\
& =43 \%
\end{aligned}
$$




\section{Kesimpulan}

Berdasarkan hasil analisis dan perhitungan baik dari aspek kualitatif dan kuantitatif, dapat ditarik beberapa kesimpulan mengenai kelayakan usaha pada pengembangan industri Casheila, di antaranya :

1. Hasil analisis studi kelayakan bisnis industri casheila dari aspek non keuangan sebagai berikut:

a. Aspek pasar dan pemasaran menunjukkan usaha yang dilakukan oleh industri Casheila cukup layak untuk dijalankan dengan melihat pasar yang luas, tetapi dalam hal pemasaran atau distribusi masih kurang maksimal dengan melihat aspek pasar yang begitu luas.

b. Aspek Teknis dan Teknologi dengan penilaian dari faktor teknis produksi lokasi, bahan baku, tenaga kerja, teknologi dan proses produksi industri Casheila dinilai layak untuk dijalankan. Dan faktor hukum dan lingkungan industri ini dinilai layak untuk dijalankan dengan adanya surat usaha, domisili, sertifikat kesehatan pangan dan sertifikasi dari MUI, dan dalam pengolahan limbah industri dikelola dengan baik dan tidak menimbulkan dampak negatif bagi masyarakat sekitar.

c. Aspek Manajemen masih belum bisa dikatakan layak, karena masih belum maksimalnya manajemen yang dilakukan oleh industri casheila dengan belum adanya pembagian kinerja yang jelas baik dalam proses produksi maupun pemasaran dan belum adanya karyawan yang sesuai yang diharapkan di Industri ini.

2. Hasil analisis dari aspek keuangan menunjukkan usaha dari industri Casheila ini dikatakan layak dijalankan dengan umur proyek selama 8 tahun pada tingkat discount rate sebesar 14\%. Analisis kriteria kelayakan menghasilkan Payback Period (PP) selama 1 tahun 1 bulan hari, nilai Net Present Value (NPV) sebesar Rp 1.191.596.184, nilai Profitability Index (PI) sebesar 4,96, dan nilai Internal Rate of Return (IRR) sebesar 24,54\%.

3. Dengan hasil sensitivitas

Secara umum dapat disimpulkan bahwa usaha ini sensitif terhadap kenaikan harga bahan baku dengan hasil analisi sebesar $43 \%$, dan tidak sensitif terhadap perubahan penurunan produksi dengan hasil sebesar $44 \%$.

Beberapa hal yang harus dikembangkan lagi dalam meningkatkan perkembangan Indsutri Casheila.

1. Harus adanya evaluasi kembali dalam menjalankan industri dan perbaikan manajemen dari Industri Casheila dan perlu memaksimalkan kinerja, merekrut karyawan tetap untuk memaksimalkan produksi dan pemasaran dari industri.

2. Bila sudah memungkinkan, dilakukan pembagian tanggung jawab atau kinerja dalam menjalankan fungsi kepengurusan agar pelaksanaan dalam menjalankan industri ini bisa lebih optimal untuk meningkatkan perkembangan industri.

3. Bagi peneliti selanjutnya, hendaknya untuk mengembangkan penelitian ini dengan menganalisis strategi perkembangan industri sehingga dapat diperoleh cara untuk mengembangkan dan memaksimalkan perkembangan industri atau UMKM.

\section{DAFTAR PUSTAKA}

Auliya, Khairul, 2012, Analisis Pelaksanaan Program Kemitraan Terhadap Perkembangan UKM Mitra Binaan PT.Perkebunan Nusantara Iii Medan, Fakultas Ekonomi Universitas Sumatera Utara Medan.

Fakhrida, Agustina, Emmy Sri Mahreda Dan Rina Mustika, 2016, Analisis Usaha Pengolahan Kerupuk Ikan Tenggiri (Scomberomorus Commersoni) Skala Rumah Tangga Di 
Kecamatan Pulau Laut Utara Kabupaten Kotabaru Provinsi Kalimantan Selatan, Vol. 12 No. 2, Halaman 63-68.

Juminang, 2011 Studi Kelayakan Bisnis (Teori dan pembuatan proposal kelayakan). PT.Bumi Aksara, Jakarta.

Nurrohmah, Isnaini, 2015, Analisis Perkembangan Usaha Mikro, Kecil Dan Menengah Sebelum Dan Sesudah Menerima Pembiayaan Musyarakah Pada Koperasi Jasa Keuangan Syariah Bmt (Studi Kasus: Bmt Beringharjo Yogyakarta), Universitas Negeri Yogyakarta.

Sunyoto, Danang. 2013. Analisis Laporan Keungan Untuk Bisnis (teori dan kasus). CAPS (Center of Academic Publishing Service). Jakarta.

Umar, Husain, 2011, Studi Kelayakan Bisnis - Teknik Menganalisis Kelayakan Rencana Bisnis Secara Komperensif, PT.Gramedia Pustaka Utama, Jakarta.

Waluyanto, Sinung, 2011, Kelayakan Usaha Dan Strategi Pengembangan Sentra Industri Konveksi Di Desa Tambakboyo Kecamatan Pedan Kabupaten Klaten, Skripsi Pada Universitas Negeri Semarang, Semrang.

Wicaksono, Fibrian Fajar Tri, 2013, Analisis Nilai Tambah Serta Kelayakan Finansial Agroindustri Keripik Singkong Di Kecamatan Patrang Kabupaten Jember, Fakultas Perntanian Universitas Jember. 